\title{
Key Production Parameters to Obtain Transparent Nanocellular PMMA
}

\author{
Judith Martín-de León,* Victoria Bernardo, and Miguel Ángel Rodríguez-Pérez
}

Transparent nanocellular polymethylmethacrylate (PMMA) with relative density around $\mathbf{0 . 4}$ is produced for the first time by using the gas dissolution foaming technique. The processing conditions and the typical characteristics of the cellular structure needed to manufacture this novel material are discovered. It is proved that low saturation temperatures $\left(-32^{\circ} \mathrm{C}\right)$ combined with high saturation pressures $(6,10,20 \mathrm{MPa})$ allow increasing the solubility of PMMA up to values not reached before. In particular, the highest $\mathrm{CO}_{2}$ uptake ever reported for PMMA, (i.e., $48 \mathrm{wt} \%$ ) is found for a saturation pressure of $20 \mathrm{MPa}$ and a saturation temperature of $-32{ }^{\circ} \mathrm{C}$. Due to these processing conditions, cell nucleation densities of $10^{16}$ nuclei $\mathrm{cm}^{-3}$ and cell sizes clearly below $50 \mathrm{~nm}$ are achieved. The nanocellular polymers obtained, with cell sizes ten times smaller than the wavelength of visible light and very homogeneous cellular structures, show a significant transparency.

\section{Introduction}

Cellular polymers have aroused much interest since the discovery of microcellular polymers in the 1980 s at Massachusetts Institute of Technology (MIT), ${ }^{[1]}$ because they present better mechanical properties than materials with bigger cell sizes. ${ }^{[2]}$ In order to further improve these materials, cell sizes were reduced up to the nanometric range, ${ }^{[3]}$ leading to nanocellular materials (cell sizes below $500 \mathrm{~nm}$ ) which present interesting properties that make them suitable for their use as insulating materials, ${ }^{[4]}$ filters and sensors, among others. ${ }^{[5]}$ In addition, nanocellular materials produced from amorphous polymers are expected to keep,up to some extent,the transparent character of the former solid, unlike microcellular materials that are all of them opaque. This potential transparency is due to the fact that if the cells are small enough compared to the wavelength of light, the material will transmit the light rather than scatter it (as occurs in microcellular materials). ${ }^{[6]}$ Transparent nanocellular materials could be potentially used to create transparent thermal insulators that could find a wide range of applications in windows of the construction and transport industries, leading to huge energy savings. ${ }^{[7]}$ As far as we know, there are no precedents of transparent nanocellular polymers produced

\footnotetext{
J. Martín-de León, V. Bernardo, Prof. M. Á. Rodríguez-Pérez Cellular Laboratory (CellMat)

Universidad de Valladolid

Valladolid 47011, Spain

E-mail: jmadeleon@fmc.uva.es
}

DOI: 10.1002/mame.201700343 from the gas dissolution foaming process, but previous studies carried out with silica aerogels (nanostructured materials presenting transparent character ${ }^{[8]}$ ) suggest that pore sizes should be around ten times smaller than the wavelength of light, and in addition the cell size distribution should be very narrow.

Previous papers have dealt with the reduction of cell sizes below $50 \mathrm{~nm}$ following different strategies. Some of them are the use of self-assembled order copolymers that can provide nanocellular structures from $100^{[9]}$ to $10 \mathrm{~nm},{ }^{[10]}$ the use of homopolymers based on polycarbonate $(\mathrm{PC})$ that can produce materials with cell sizes of $20-30 \mathrm{~nm}^{[7]}$ or the use of polyphenylsulfone (PPSU) as raw material that allows producing cellular polymers with cell sizes of $20-30 \mathrm{~nm}^{[11]}$ However, the authors of these papers did not analyse the possible transparency of these systems. On the other hand, one of the most studied systems for the production of nanocellular materials has been polymethylmethacrylate (PMMA) due to its high affinity with $\mathrm{CO}_{2}$. In order to reduce the cell size of this system the solubility of PMMA homopolymer have been improved by means of two different strategies, increasing the saturation pressure $\left(p_{\text {sat }}\right)^{[12]}$ or decreasing saturation temperature $\left(T_{\text {sat }}\right)$ (reaching cell sizes of $35 \mathrm{~nm}) .{ }^{[13]}$ But the combination of the two previous strategies at the same time has not been explored.

Taking the previous information in mind, the objective of this work is to produce transparent nanocellular materials based on a PMMA homopolymer. In order to do that the $\mathrm{CO}_{2}$ solubility in the material has been maximized by using $T_{\text {sat }}$ of $-32{ }^{\circ} \mathrm{C}$ and $p_{\text {sat }}$ of 6,10 , and $20 \mathrm{MPa}$ simultaneously, exploring these limits for the first time. This method results in an improvement in cell nucleation densities of two orders of magnitude and smaller cell sizes compared with results obtained up to date. Moreover, the materials with cell sizes below $40 \mathrm{~nm}$ show a signficant degree of transparency.

\section{Experimental Section}

\subsection{Materials}

PMMA V825T was kindly supplied by ALTUGLAS International (Colombes, France) in the form of pellets. The material used presented a density $(\rho)$ of $1.19 \mathrm{~g} \mathrm{~cm}^{-3}$ (measured at $23{ }^{\circ} \mathrm{C}$ and $50 \%$ relative humidity (HR)), a melt flow index of $1.92 \mathrm{~g}$ per $10 \mathrm{~min}$ 
$\left(230{ }^{\circ} \mathrm{C}\right.$ per $\left.2.16 \mathrm{~kg}\right)$, and a glass transition temperature $\left(T_{\mathrm{g}}\right)$ of $114.5^{\circ} \mathrm{C}$ measured by differential scanning calorimetry (DSC).

Medical grade $\mathrm{CO}_{2}$ (99.9\% purity) was used as blowing agent.

\subsection{Samples Production}

The PMMA pellets were processed by using a hot plate press so as to obtain cylindrical $2 \mathrm{~mm}$ thick sheets. The material was first heated at $250{ }^{\circ} \mathrm{C}$ during 9 min without applying any pressure. Afterward, it was pressed under a constant pressure of $2.2 \mathrm{MPa}$ for $1 \mathrm{~min}$. Finally, the material was cooled down at room temperature under the same pressure.

These sheets were later cut in order to obtain $20 \times 20 \times 2 \mathrm{~mm}^{3}$ samples for the foaming tests.

\subsection{Foaming Test}

Foaming tests were carried out in a high pressure vessel (model PARR 4760) provided by Parr Instrument Company (Moline, IL, USA). In order to work up to $20 \mathrm{MPa}$, the pressure system comprised an accurate pressure pump controller (model SFT10) provided by Supercritical Fluid Technologies Inc. (Neward, DE, USA). The pressure vessel was placed inside a freezer which allowed controlling the saturation temperature from 0 to $-32{ }^{\circ} \mathrm{C}$. Thermal baths (J.P. Selecta Model 600685, Grupo Selecta, Barcelona, Spain) were used for the foaming after the saturation of the samples. A set of gas dissolution foaming experiments were done by using this set up. Gas dissolution foaming process consisted of three steps, saturation, desorption, and foaming. Samples were initially saturated under certain conditions of $\mathrm{CO}_{2}$ pressure and temperature. Pressure gas was fast released in the second step, and after the desorption time $\left(t_{\mathrm{d}}\right)$ samples were immersed in a thermal bath for foaming.

In this work, $T_{\text {sat }}$ was fixed to be $-32{ }^{\circ} \mathrm{C}$ in all the experiments. On the other hand, $p_{\text {sat }}$ was varied $(6,10$, and $20 \mathrm{MPa})$ in order to study its influence on the final cellular structure. Saturation time was $5 \mathrm{~d}$ for every experiment in order to ensure the complete saturation of the samples. ${ }^{[14]}$ Pressure was released at a ratio of $1 \mathrm{MPa} \mathrm{s}^{-1}$. $t_{\mathrm{d}}$ was $2 \mathrm{~min}$ for all the experiments. For the foaming step, three different foaming temperatures $\left(T_{\mathrm{f}}\right)$ $\left(25,40\right.$, and $\left.60^{\circ} \mathrm{C}\right)$ are used. Foaming time $\left(t_{t}\right)$ was 2 min.

\subsection{Characterization Techniques}

\subsection{Density}

Density of solid samples $\left(\rho_{\mathrm{s}}\right)$ was determined by means of a gas pycnometer (Mod. AccuPyc II 1340, Micromeritics, Norcross, GA, USA). Density of foamed samples $\left(\rho_{\mathrm{f}}\right)$ was measured with the water displacement method, based on Archimedes' principle. A density determination kit for an AT261 Mettler-Toledo balance was used for this purpose. Relative density $\left(\rho_{\mathrm{r}}\right)$ was calculated as the ratio between $\rho_{\mathrm{f}}$ and $\rho_{\mathrm{s}}\left(\rho_{\mathrm{r}}=\rho_{\mathrm{f}} / \rho_{\mathrm{s}}\right)$. The solid skin, characteristic of this process and presenting maximum values of $50 \mu \mathrm{m}$, was removed by means of a polisher (model
LaboPO12-LaboForce3, Struers (Ballerup, Dinamarca))before measuring $\rho_{\mathrm{f}}$. $200 \mu \mathrm{m}$ was removed on each side of the sample.

\subsubsection{Amount of Gas Uptake}

The amount of $\mathrm{CO}_{2}$ uptake was calculated as the percentage of weight increment of the sample due to the gas sorption. The final weight of the samples was extrapolated to zero time using the desorption curve (mass lost vs time plot), which was registered with a Mettler-Toledo balance. The value of mass when the curve was extrapolated to zero desorption time was considered as the mass of the sample under the saturation conditions used, i.e., the solubility of the material.[15]

\subsubsection{Scanning Electron Microscopy (SEM)}

In order to maintain the cellular structure for SEM visualization, samples were cooled down in liquid nitrogen and then cut using a Leica microtome at $-120^{\circ} \mathrm{C}$. Then they were coated with around $10 \mathrm{~nm}$ of gold by using a sputter coater (model SDC 005, Balzers Union, Balzers, Liechtenstein). An ESEM Scanning Electron Microscope (QUANTA 200 FEG, Hillsboro, OR, USA) was used to obtain images of the cellular structure. In order to analyse the SEM micrographs, a software based on ImageJ/FIJ ${ }^{[16]}$ was used. Cell nucleation density $\left(N_{0}\right)$ was measured by using the Kumar method ${ }^{[17]}$ while the 3D cell size $(\phi)$ was calculated by averaging the cell size measurement of a satisfactory number of cells (more than 200). The cell size distribution as well as the standard deviation of the cell size distribution (SD) was also measured for each material. Finally, the standard deviation divided by the cell size $(\mathrm{SD} / \phi)$ was calculated in order to characterize the homogeneity of the cellular structure.

Due to the small cell size of the samples, some aspects needed to be taken into account regarding the values of this structure characteristic. On the one hand, the gold coating was reducing the measured cell size in $\approx 20 \mathrm{~nm}$. On the other hand, the gold coating was covering the smaller cells. Therefore, the reported cell size was an average of the sizes of visible cells. Despite these two facts, the provided values were comparable with those reported using the same methodology.

\subsubsection{Transparency}

In order to test the transparency of each material, $1 \mathrm{~mm}$ thick samples were cut off by from the foamed materials by means of a precision cutting machine (Mod.1000 IsoMet). Samples obtained were completely plane parallel and presented a homogenous thickness.

\section{Results and Discussion}

\subsection{Gas Uptake}

As expected, solubility increases as saturation pressure becomes higher (Figure 1 (Left)). ${ }^{[18]}$ A extremely high solubility (39 wt\%) 

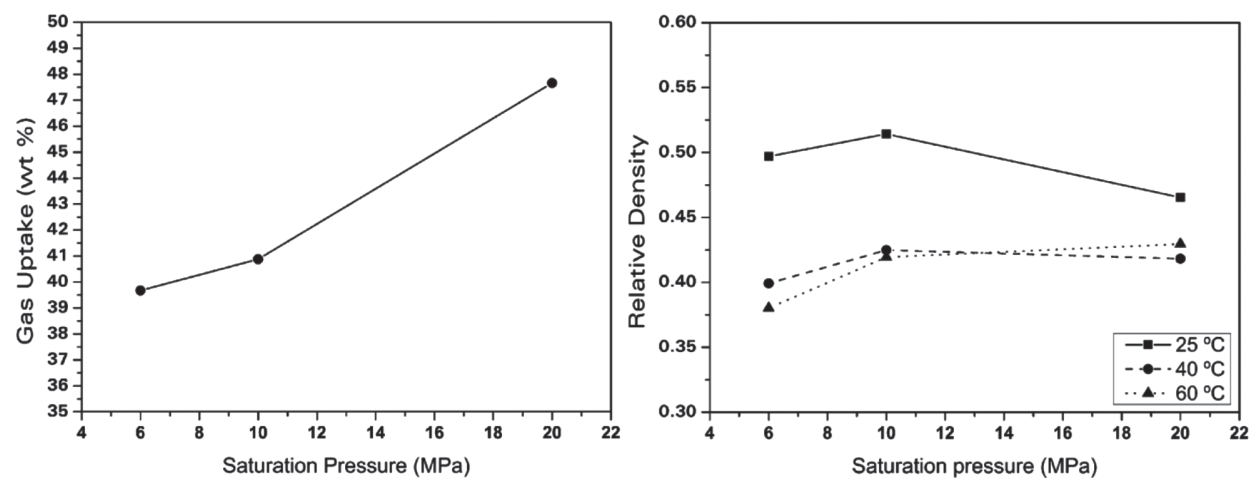

Figure 1. Gas uptake as a function of saturation pressure for a constant saturation temperature of $-32^{\circ} \mathrm{C}$. (Left). Relative density as a function of the saturation pressure for different foaming temperatures. (Right).

was obtained by decreasing $T_{\text {sat }}$ up to $-32{ }^{\circ} \mathrm{C}$ and using $6 \mathrm{MPa}$ of $p_{\text {sat }}{ }^{[14]}$ By maintaining this low $T_{\text {sat }}$ but increasing the $p_{\text {sat }}$ up to $20 \mathrm{MPa}$, it has been possible to achieve a solubility of $48 \%$, which is to our knowledge, the highest $\mathrm{CO}_{2}$ solubility ever reported for PMMA.

\subsection{Relative Density}

Figure 1 (Right) shows that relative density hardly changes with $p_{\text {sat }}$ while it sharply decreases by increasing the $T_{\mathrm{f}}$ from 25 to $40{ }^{\circ} \mathrm{C}$, but when the temperature is increased to $60{ }^{\circ} \mathrm{C}$ relative density is no longer reduced. It can be also observed that for $20 \mathrm{MPa}, \rho_{\mathrm{r}}$ is almost constant for all the foaming conditions.

In order to analyse the effect of $p_{\text {sat }}$ in the final cellular structure samples foamed at $40{ }^{\circ} \mathrm{C}$ have been selected.

\subsection{Cellular Structure}

SEM micrographs of the cellular structures obtained as well as the cell size distribution are shown in Figure 2 while the rest of the obtained data are presented in Figure 3 and Table 1. Figure 2 shows a significant reduction of cell size when saturation pressure is increased.

As it can be seen in Figure 3 and Table 1, the increase of the amount of gas uptake from 39 to $48 \mathrm{wt} \%$ implies an increase of $N_{0}$ from $1.2 \times 10^{16}$ to $6.9 \times 10^{16}$ nuclei $\mathrm{cm}^{-3}$. Otherwise cell size decreases remarkably from $40 \mathrm{~nm}$ to almost $10 \mathrm{~nm}$.

On the other hand, changes in the cell size distribution (Figure 2, down) can be also observed. As $\phi$ becomes smaller the width of the cell size distribution (quantified by $\mathrm{SD} / \phi$ ) decreases from 0.3 to 0.2 , which means that the cell size distribution is more homogeneous.
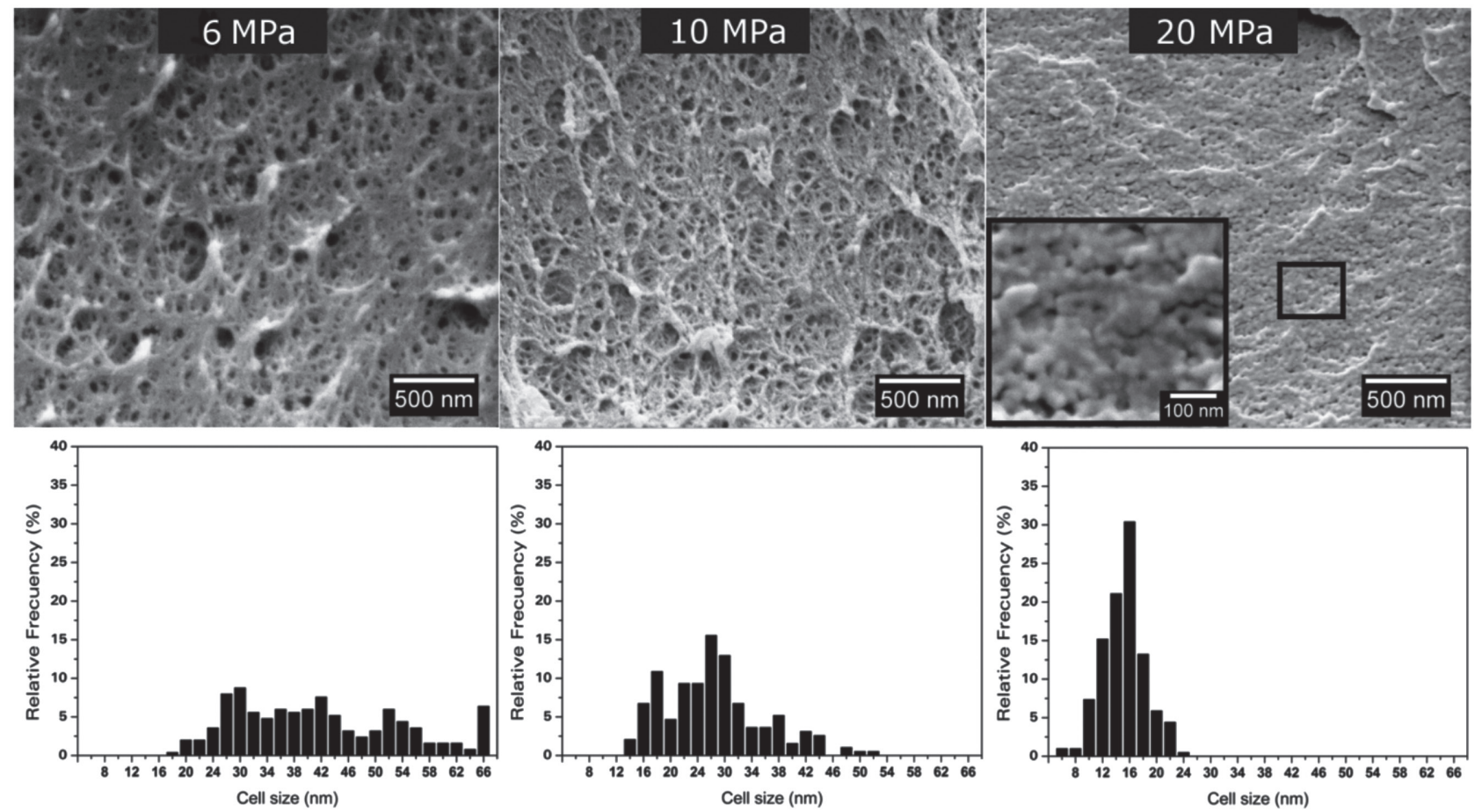

Figure 2. SEM images (up) and cell size distributions (down) of samples foamed at $40^{\circ} \mathrm{C}$ during 2 min for the three different saturation pressures. 


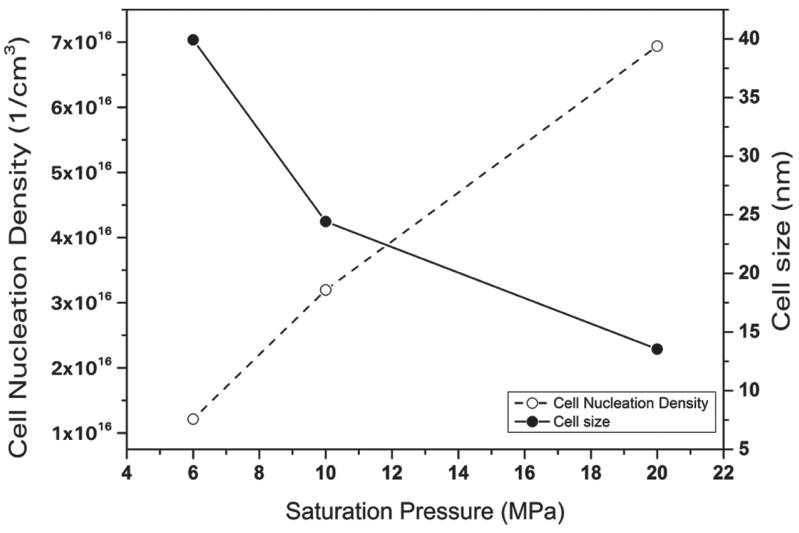

Figure 3. Cell nucleation density and cell size as a function of saturation pressure for samples foamed at $40{ }^{\circ} \mathrm{C}$ during $2 \mathrm{~min}$.

It can be concluded that it is possible to obtain samples with the same relative density but with different $N_{0}$ and $\phi$, only by changing the amount of gas absorbed. Using a $p_{\text {sat }}$ of $20 \mathrm{MPa}$ and a $T_{\text {sat }}$ of $-32{ }^{\circ} \mathrm{C}$, values of $N_{0}$ as high as $7 \times 10^{16}$ nuclei $\mathrm{cm}^{-3}$ and $\phi$ around $10 \mathrm{~nm}$ can be obtained. These values have not been reported for PMMA before.

\subsection{Transparency}

Figure 4 shows a comparison between the $1 \mathrm{~mm}$ thick samples of this study and one sample produced at $31 \mathrm{MPa}$ of saturation pressure and $25{ }^{\circ} \mathrm{C}$ of saturation temperature. ${ }^{[12]}$ This sample has a cell size of $225 \mathrm{~nm}$ and relative density of 0.43 .

As it is shown in this figure, while the material with a cell size of $250 \mathrm{~nm}$ is fully opaque, the materials produced in this research are transparent and as expected transparency increases as cell size becomes smaller.

As it has been previously reported for aerogels, to obtain transparent nanocellular polymers cell size should be clearly below the wavelength of visible light (400-750 nm). It is needed

Table 1. Cell nucleation density, cell size, and SD/ $\Phi$ for the samples foamed at $40^{\circ} \mathrm{C}$ during $2 \mathrm{~min}$ for the three different pressures.

\begin{tabular}{|c|c|c|c|}
\hline $\begin{array}{l}\text { Saturation pressure } \\
\text { [MPa] }\end{array}$ & $\begin{array}{c}N_{0} \\
\text { [nuclei } \mathrm{cm}^{-3} \text { ] }\end{array}$ & $\begin{array}{l}\text { Cell size } \\
{[\mathrm{nm}]}\end{array}$ & $\mathrm{SD} / \Phi$ \\
\hline 6 & $1.2 \times 10^{16}$ & 39 & 0.27 \\
\hline 10 & $3.2 \times 10^{16}$ & 24 & 0.23 \\
\hline 20 & $6.9 \times 10^{16}$ & 14 & 0.19 \\
\hline
\end{tabular}

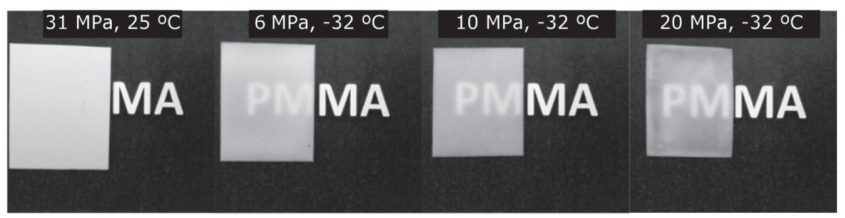

Figure 4. Transparency of the samples produced at three different saturation pressures, compared with a sample of $225 \mathrm{~nm}$ of cell size and the same relative density. to reach cells sizes around $40 \mathrm{~nm}$ for relative densities of around 0.4 to achieve an appreciable transparency (Figure 4).

The material showing the higher transparency is the one showing a smaller cell size and the more homogeneous cell size distribution. It seems that in materials with higher average cell size the presence of cells with diameters bigger than $60 \mathrm{~nm}$ are presumably increasing the scattering and therefore reducing the transparency of the material.

\section{Conclusions}

Nanocellular materials based on PMMA have been produced by using a $T_{\text {sat }}$ of $-32{ }^{\circ} \mathrm{C}$ and three different $p_{\text {sat }}(6,10$, and $20 \mathrm{MPa}$ ). Changes the saturation pressure increases the amount of gas uptake from 39 to $48 \mathrm{wt} \%$ which has permitted to rise cell nucleation densities of $7 \times 10^{16}$ nuclei $\mathrm{cm}^{-3}$ at $20 \mathrm{MPa}$ and to decrease of the cell size to $14 \mathrm{~nm}$. The effect of changing the foaming conditions has been also studied. Higher relative density are obtained with a $T_{f}$ of $25^{\circ} \mathrm{C}$, while 40 and $60^{\circ} \mathrm{C}$ produce materials with smaller and similar relative densities (0.4). In addition, thanks to the reduced cell size obtained (10 times lower than the wavelength of visible light) and the very homogenous cellular structure, transparent nanocellular polymers have been successfully produced for the first time. The possibility of producing transparent nanocellular polymer opens a wide range of potential applications for these novel materials.

\section{Acknowledgements}

Financial assistance from MINECO, FEDER, UE (MAT2015-69234-R), and the Junta de Castile and Leon (VA011U16) are gratefully acknowledged. Financial support from Junta of Castile and Leon grant Q4718001C (J.M.L.) and FPU grant FPU14/02050 (V.B.) from the Spanish Ministry of Education is gratefully acknowledged.

\section{Conflict of Interest}

The authors declare no conflict of interest.

\section{Keywords}

gas dissolution foaming, high solubility, nanocellular foam, PMMA, transparent nanocellular polymer

Received: July 12, 2017

Revised: August 31, 2017

Published online: October 17, 2017

[1] D. Eaves, Handbook of Polymer Foams, Rapra Technology Limited, Munich, Germany, UK 2004.

[2] K. Nadella, V. Kumar, Exp. Anal. Nano Eng. 2007, 765.

[3] M. N. Bureau, J. Cell. Plast. 2006, 42, 229.

[4] C. Forest, P. Chaumont, P. Cassagnau, B. Swoboda, P. Sonntag, Prog. Polym. Sci. 2015, 41, 122.

[5] S. Costeux, J. Appl. Polym. Sci. 2014, 131, 4293. 
[6] A. J. Hunt, P. Berdahl, Material Research Society Symposium Proceedings 1984, 32, 275.

[7] H. Guo, V. Kumar, Polymer 2015, 56, 46.

[8] M. Schmidt, F. Schwertfeger, J. Non-Cryst. Solids 1998, 225, 364.

[9] T. Shinkai, M. Ito, K. Sugiyama, K. Ito, H. Yokoyama, Soft Matter 2012, 5811.

[10] C. Dutriez, K. Satoh, K. Masami, H. Yokoyama, RSC Adv. 2012, 2, 2821.

[11] V. Bernardo, J. Martín-de León, M. A. Rodríguez-Pérez, Materials Letters 2016, 178, 155.
[12] J. Martín-de León, V. Bernardo, M. Rodríguez-Pérez, Polymers 2016, 8, 265.

[13] H. Guo, A. Nicolae, V. Kumar, Polymer 2015, 70, 231.

[14] H. Guo, V. Kumar, Polymer 2015, 57, 157.

[15] M. Tang, T.-B. Du, Y.-P. Chen, J. Supercrit. Fluids 2004, 28, 207.

[16] J. Pinto, E. Solorzano, M. A. Rodriguez-Perez, J. A. de Saja, J. Cell. Plast. 2013, 49, 555.

[17] V. Kumar, N. P. Suh, Polym. Eng. Sci. 1990, 30, 1323.

[18] K. F. Webb, A. S. Teja, Fluid Phase Equilib. 1999, 158-160, 1029. 